\title{
Kinerja Pendekatan Convolutional Neural Network dan Dense Network dalam Klasifikasi Citra Malaria
}

\author{
Achmad Dafid $^{1 *}$, Ponco Siwindarto ${ }^{1}$, Bambang Siswojo ${ }^{1}$ \\ ${ }^{1}$ Prodi Teknik Elektro Fakultas Teknik Universitas Brawijaya \\ JI. MT. Haryono No.167 Ketawanggede Lowokwaru Kota Malang 65145 Jawa Timur \\ *achdafid@student.ub.ac.id \\ DOI: https://doi.org/10.21107/rekayasa.v14i2.10735
}

\begin{abstract}
Indonesia is an archipelago, which three of its five main island consists mainly, or dense tropical rainforest. This rainforest is main breeding ground for malaria disease that mostly affect regions near said forest. In an effort to treat malaria disease, a diagnostic process is performed to correctly identify the disease. Several image pattern recognition technique been developed and have potential to be utilized as malaria diagnostic tool. In this research, a method is described on designing neural network to detect a blood cell parasitized by malaria. The method consists of utilizing a dense network, and a convolutional neural network, to be trained using publicly available training dataset. Both models' performance is then compared and analyzed. Before the data is used, a process of padding is performed to resize the input image into $200 \times 200$ pixels. The resized input data is then used to train both models. From the training and testing, it is found that the dense network achiever 64.78\% accuracy. On the other hand, model based on convolutional neural network achiever $94.32 \%$. From analysis, it is found that the size of the model being used is not big enough to achieve better performance. Hence, it is suggested for future research to increase the model size in terms of network width and depth.
\end{abstract}

Keywords : convolutional neural network, dense layer, deep learning, classification, malaria cell

\section{PENDAHULUAN}

Indonesia merupakan negara kepulauan, dengan lima pulau utama, yaitu Jawa, Sumatera, Kalimantan, Sulawesi, dan Papua. Selain pulau Jawa, sebagian besar daerah pulau-pulau utama ini, masih berupa hutan rimba, terutama pada pulau Kalimantan, Sulawesi, dan Papua. Luasanya areal hutan ini menjadi area rawan penularan penyakit Malaria, yang ditularkan oleh nyamuk Anophles betina. Penularan ini terutama terjadi pada kawasan timur Indonesia (Primadi, 2017).

Dalam proses pengobatan terhadap penyakit malaria, salah satu tahapan utamanya adalah diagnosis terhadap pasien. Standar emas dalam diagnosis malaria adalah dengan melakukan pemeriksaan mikroskopis terhadap citra thick smear atau thin smear sampel darah pasien, untuk kemudian diperiksa oleh tenaga medis berkualifikasi (Centers for Disease Control and Prevention, 2020). Apabila parasit plasmodium terdeteksi dalam darah, maka sampel diklasifikasikan sebagai terinfeksi, dan pasien

\section{Article History:}

Received: May, 19 $9^{\text {th }}$ 2021; Accepted: July, $2^{\text {nd }} 2021$

Rekayasa ISSN: $2502-5325$ has been Accredited by Ristekdikti (Arjuna) Decree: No. 23/E/KPT/2019 August 8th, 2019 effective until 2023 diklasifikasikan sebagai pengidap malaria dan harus menjalani perawatan lebih lanjut.

Permasalahan utama dari metode diagnostik ini adalah pemeriksaan terhadap sampel mikroskopis sering tidak dapat dilakukan secara langsung, karena masalah keterbatasan dan ketersediaan tenaga medis berkualifikasi untuk melakukan pemeriksaan visual terhadap citra thick smear atau thin smear sampel darah. Karena itu, diperlukan suatu solusi untuk permasalahan ini, dimana salah satunya adalah melakukan pemeriksaan ada tidaknya parasite plasmodium dalam sampel darah secara otomatis, dengan menggunakan bantuan teknologi. Secara khusus teknologi untuk klasifikasi citra dapat digunakan untuk inspeksi sampel darah secara otomatis.

Beberapa penelitian sebelumnya telah membahas mengenai klasifikasi citra sampel darah untuk diagnosis malaria secara cepat, diantaranya dengan pendekatan berbasis machine learning oleh

\section{Cite this as:}

Dafid, A, Siwindarto, P \& Siswojo, B. (2021). Kinerja Pendekatan Convolutional Neural Network dan Dense Network dalam Klasifikasi Citra Malaria. Rekayasa 14 (2). 222-229. doi: https://doi.org/10.21107/rekayasa.v14i2.10735.

(C) 2021 Achmad Dafid 
(Poostchi, Silamut, Maude, Jaeger, \& Thoma, 2018) dan (Bias, Reni, \& Kale, 2018), dan pendekatan berbasis neural network oleh (Pattanaik, Mittal, Khan, \& Panda, 2020), dan (Rajendran, Balasubramanian, \& Rajinikanth, 2020). Dari beberapa penelitian tersebut, hasil terbaik dari penelitian tersebut mampu mencapai tingkat akurasi $98.07 \%$. Namun, perlu ada penelitian lanjutan untuk mencapai tingkat akurasi yang lebih baik dibandingkan hasil yang telah dicapai penelitian sebelumnya. Salah satu solusi yang lebih potensial adalah dengan menggunakan model ResNet (He, Zhang, Ren, \& Sun, 2016) yang pada dataset citra CIFAR-10 mampu mencapai tingkat akurasi hingga $99.37 \%$.

ResNet sendiri memiliki konsep yang memanfaatkan skip connection antara lapisan dalam neural network. Dan pada lapisan-lapisan dalam model ini, digunakan model komputasi berbasis convolutional neural network yang diusulkan oleh (LeCun, Bottou, Bengio, \& Haffner, 1998), dan perceptron dalam bentuk dense network yang pertama kali diusulkan oleh (Rosenblatt, 1958). Sebagai salah satu metode tambahan yang diharapkan dapat meningkatkan kinerja dari model yang akan dibuat, dapat dilakukan augmentasi data seperti ditunjukkan oleh (Shorten \& Khoshgoftaar, 2019) terhadap dataset pelatihan oleh (Jaeger, 2019) yang akan digunakan.

Atas dasar tersebut, maka penelitian ini akan membuat model berbasis convolutional neural network dan dense network untuk deteksi malaria. Diharapkan penelitian ini akan menghasilkan sistem deteksi yang lebih baik tingkat akurasinya dibandingkan penelitian sebelumnya, dan dapat menjadi referensi untuk pengembangan metode diagnosis penyakit malaria selanjutnya.

\section{METODE PENELITIAN}

\section{Jenis dan Cara Perolehan Data}

Dua jenis data kuantitatif akan digunakan dalam penelitian ini. Data pertama adalah data yang berasal dari dataset sel malaria yang berasal dari (Jaeger, 2019). Dataset ini akan digunakan sebagai data masukan dalam proses pembelajaran, serta digunakan dalam saat melakukan validasi terhadap model neural network yang telah dibuat. Data kedua adalah data mengenai model neural network yang akan dibuah yaitu sebuah model dense network, dan sebuah model convolutional neural network. Parameter akan berubah mengikuti proses pembelajaran, namun hyperparameter dari masingmasing model akan ditetapkan pada tahapan ini.

\section{Tahapan Penelitian}

Prosedur untuk menjawab permasalahan yang ada, ditunjukkan pada diagram alir Gambar 1. Prosedur dimulai dengan melakukan preprocessing terhadap data, untuk kemudian digunakan sebagai bahan pelatihan terhadap model neural network yang dibuat. Tahapan-tahapan dalam kegiatan penelitian ini dijabarkan sebagai berikut:

\section{Preprocessing Data}

Tahapan preprocessing data pada penelitian ini, dikhususkan untuk melakukan pengolahan awal yang akan mendukung kinerja pelatihan, dan kinerja model neural network secara keseluruhan, yaitu dengan menggunakan teknik-teknik Augmentasi Data. Transformasi, distorsi, dan beberapa teknik augmentasi data yang telah terbukti dapat meningkatkan kinerja neural network secara keseluruhan, akan digunakan pada tahap ini.

2. Pembuatan model dense network

Pada tahapan ini, dibuat sebuah model komputasional dense network, dengan menggunakan kit perangkat lunak yang telah dipilih. Pada penjelasan tahapan ini akan dijelaskan lebih lanjut mengenai arsitektur dan model komputasi yang digunakan.

3. Pembuatan model convolutional neural network

Pada tahapan ini, dibuat sebuah model komputasional convolutional neural network, dengan menggunakan kit perangkat lunak yang telah dipilih. Pada penjelasan tahapan ini akan dijelaskan lebih lanjut mengenai arsitektur dan model komputasi yang digunakan.

4. Pelatihan terhadap kedua model

Pada tahapan ini, dilakukan pelatihan terhadap kedua model neural network yang telah dibuat, dengan menggunakan data sel malaria yang telah disiapkan dan dilakukan preprocessing. Pelatihan ini bertujuan untuk melatih parameter dari kedua model dengan harapan untuk dapat dapat melakukan deteksi yang efektif.

5. Evaluasi kinerja kedua model

Pada tahapan ini, dilakukan evaluasi terhadap model dengan cara memberikan data yang belum pernah dilihat sebelumnya oleh model, dan membandingkannya dengan label data yang sebenarnya. Diharapkan tidak terdapat perbedaan yang signifikan antara akurasi saat pelatihan dan pengujian. 
6. Perbandingan dan analisis kinerja kedua model Pada tahapan akhir, dilakukan analisis terhadap kinerja kedua model neural network yang telah dibuat.

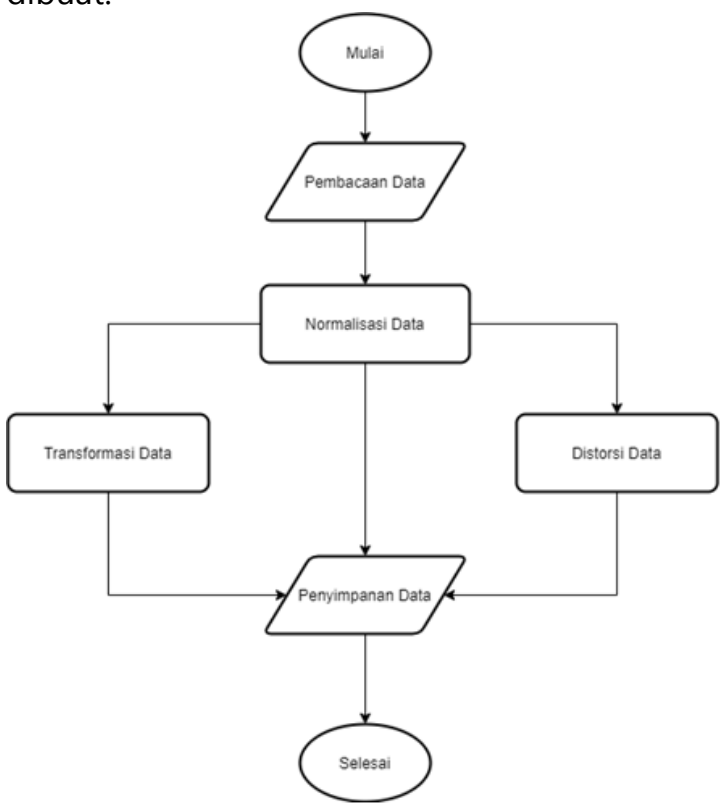

Gambar 1. Diagram Alir Augmentasi Data Sel Malaria

\section{Pembuatan Model Dense Network}

Pada tahapan kedua, akan dilakukan penyusunan untuk model dense network, dengan menggunakan perangkat lunak. Rancang bangun dari model untuk dense network yang akan dibuat ditunjukkan pada Gambar 2. Rancang bangun ini terdiri dari simpul masukan data, lapisan flattening yang mengubah bentuk data matriks menjadi bentuk vektor, beberapa buah lapisan neural network yang menggunakan basis perceptron dalam bentuk dense layer, dan diakhiri dengan sebuah lapisan logits yang merupakan sebuah fungsi maksima untuk menentukan kelas dari citra sel yang dideteksi, apakah termasuk kelas sel yang terinfeksi, atau kelas sel yang tidak terinfeksi.

Pada titik masukan data, masalah yang akan timbul adalah dari bentuk data masukan citra sel darah malaria, yang memiliki ukuran yang berbedabeda. Telah ada cara untuk mengatasi permasalahan ini antara lain dengan tidak menspesifikasikan batasan pada ukuran data citra masukan. Seluruh citra yang akan digunakan dalam proses pembelajaran akan dimasukkan kedalam model ini melalui titik masukan data ini.

Pada lapisan pertama setelah titik masukan data, ditempatkan sebuah flattening layer. Lapisan ini tidak memiliki parameter apa-apa, dan fungsi utama dari lapisan ini hanyalah merubah data dari bentuk matriks 2 dimensi menjadi data vektor 1 dimensi untuk keperluan pemrograman menggunakan software library yang diperlukan. Persamaan pada lapisan ini menggunakan persamaan sebagaimana Persamaan 1. Tergantung pada bentuk data masukan, lapisan ini akan menghasilkan ukuran luaran yang sama, dengan menambahkan padding data 0 pada setiap masukan yang memiliki ukuran kurang dari ukuran data maksimum yang telah ditetapkan.

Dimana:

$$
y_{i+(n * j)}=x_{i, j}
$$

y : : unsur luaran flattening layer

$\mathrm{x}$ : unsur masukan flattening layer

$\mathrm{n} \quad$ : jumlah baris dari masukan

i : indeks baris masukan

j : indeks kolom luaran

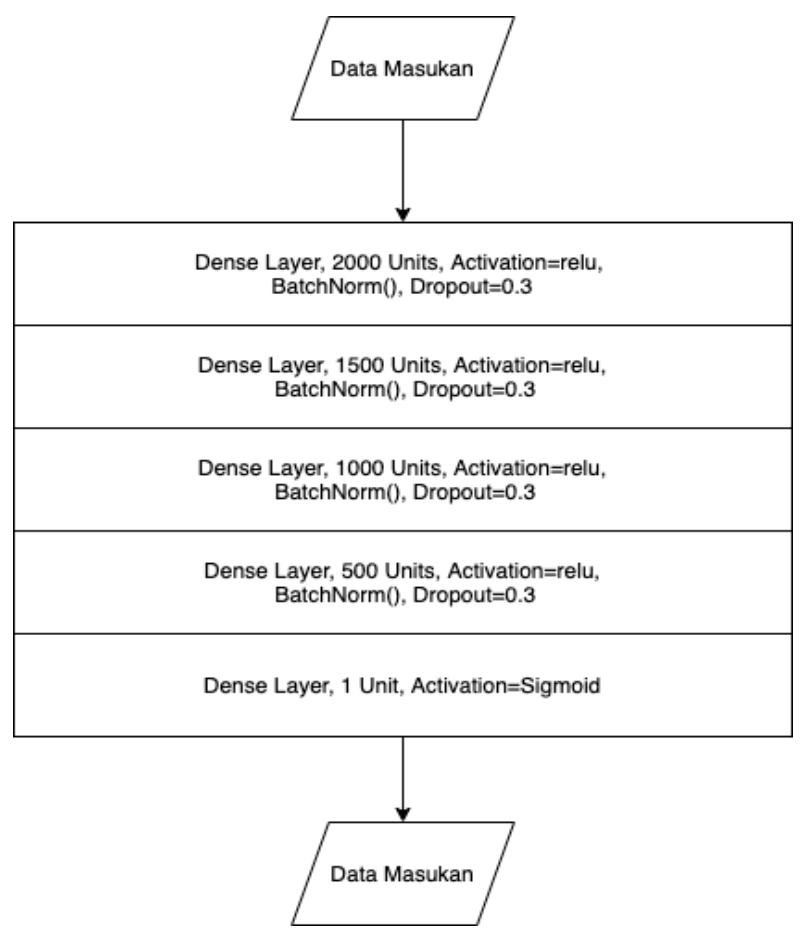

Gambar 2. Rancang Bangun Model Dense Layer

Kemudian, pada tiap-tiap lapisan dense network yang berbasis perceptron, akan digunakan rumus perhitungan yang mengikuti konsep perceptron. Pada lapisan ini, tiap-tiap nilai dari masukan terhubung secara penuh dengan semua luaran. Persamaan matematis yang akan digunakan pada model komputasi pada lapisan dense layer ini akan melibatkan parameter bobot pada tiap hubungan antar neuron masukan dengan neuron luaran, penambahan nilai bias, dan diakhiri dengan memasukkan nilai luaran kedalam sebuah activation function. Persamaan matematisnya mengikuti Persamaan 2.

$$
y_{i}=f_{a}\left(w_{1, j} \cdot x_{1}+w_{2, j} \cdot x_{2}+\cdots+w_{n, i} x_{n}+b_{i}\right)
$$


Dimana:

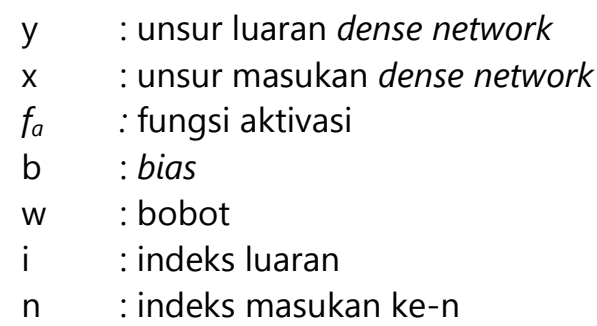

Sebagai luaran untuk memenuhi fungsi klasifikasinya, digunakan logits layer yang menghasilkan sebuah nilai probabilitas bahwa suatu citra sel darah termasuk dalam suatu kategori. Untuk mendapatkan nilai probabilitas dari sebuah citra termasuk kedalam suatu kategori tertentu (sel terinfeksi, atau sel tidak terinfeksi malaria) digunakan fungsi softmax. Fungsi softmax ini ditunjukkan pada Persamaan 3.

Dimana:

$$
\sigma(\vec{z})_{i}=\frac{e^{z_{i}}}{\sum_{j=1}^{K} e^{z_{j}}}
$$

$\vec{Z} \quad$ : Vektor masukan yang terdiri dari $\left(Z_{0}, Z_{1}, \ldots, Z_{k}\right)$

$\mathrm{Z}_{\mathrm{i}} \quad$ : Nilai ke i dari vektor masukan

$e^{z_{i}}$ : fungsi eksponensial standar dengan pangkat $z_{i}$

$\sum_{j=1}^{K} e^{z_{j}}$ : Nilai untuk melakukan normalisasi

$\mathrm{K} \quad$ : jumlah kelas dalam klasifikasi

\section{Pembuatan Model Convolutional Neural Network}

Pada tahapan ketiga, akan dilakukan penyusunan arsitektur untuk model yang berbasis convolutional neural network, dengan menggunakan perangkat lunak. Model ini terdiri dari dua buah convolutional layer, dua buah pooling layer (2x2), dan sebuah dense layer. Titik masukan data pada model ini telah membentuk matriks yang dibutuhkan. Namun karena masukan yang berbeda, maka dilakukan suatu padding terhadap data masukan, yaitu dengan menambahkan data 0 pada setiap unsur yang lebih kecil dari batas maksimum ukuran citra masukan. Dengan melakukan padding terhadap data masukan ini, tidak diperlukan proses pengubahan ukuran masukan data citra agar menjadi satu ukuran tertentu.

Kemudian, dari titik masukan, data akan melalui Persamaan komputasional untuk setiap lapisan convolutional dijabarkan sebagaimana Persamaan 4. Lapisan convolutional pertama, digunakan sebagai masukan untuk lapisan convolutional kedua, memiliki 32 buah kernel. Kernel yang digunakan berukuran $3 \times 3$, dan menggunakan padding 'same'.

$$
\begin{aligned}
y_{i, j, n}^{m}=x_{i, j}^{m} \cdot K_{i, j, n} & +x_{i+1, j}^{m} \cdot K_{i+1, j, n}+x_{i+2, j}^{m} \cdot K_{i+2, j, n} \\
& +x_{i, j+1}^{m} \cdot K_{i, j+1, n}+\cdots \\
& +x_{i+2, j+2}^{m} \cdot K_{i+2, j+2, n}+b_{i, j}
\end{aligned}
$$

Dimana:

$$
\begin{array}{ll}
\text { y } & \text { : unsur luaran konvolusi } \\
\mathrm{x} & \text { : unsur masukan konvolusi } \\
\mathrm{K} & \text { : kernel konvolusi } \\
\mathrm{b} & \text { : bias } \\
\mathrm{m} & \text { : indeks citra } \\
\mathrm{n} & \text { : indeks feature maps pada luaran konvolusi } \\
\mathrm{i} & \text { : indeks baris matriks citra } \\
\mathrm{j} & \text { : indeks kolom matriks citra }
\end{array}
$$

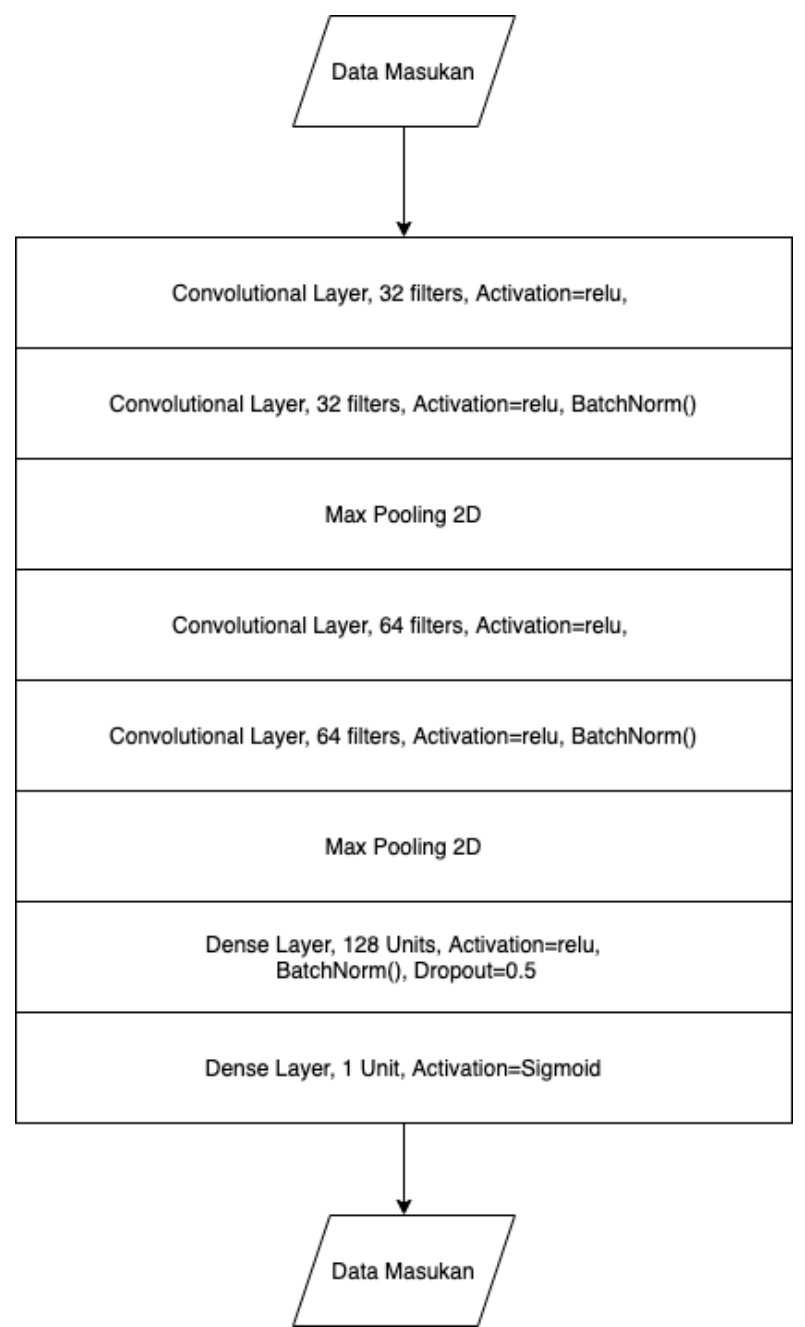

Gambar 3. Rancang Bangun Model Convolutional Neural Network

Pada lapisan konvolusi, persamaan tersebut digunakan untuk input dengan menggunakan masing-masing kernel, sehingga tiap-tiap kernel akan menghasilkan sebuah feature maps. Feature maps ini kemudian dimasukkan kedalam sebuah lapisan pooling. Persamaan komputasional untuk 
lapisan pooling ini ditunjukkan pada Persamaan 5. Lapisan ini akan mengekstrak ciri yang telah didapatkan oleh masing-masing filter, sekaligus memperkecil ukuran dari feature maps sebagai masukan kedalam convolutional layer berikutnya.

$y_{i, j, n}^{m}=\max \left(x_{2 i-1,2 j-1, n}^{m}, x_{2 i, 2 j-1, n}^{m}, x_{2 i-1,2 j, n}^{m}, x_{2 i, 2 j, n}^{m}\right)$

Dimana:

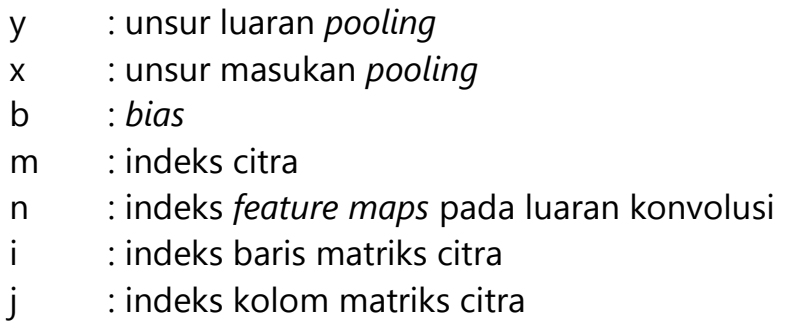

\section{HASIL DAN PEMBAHASAN}

Eksplorasi awal terhadap data, dilakukan untuk mengetahui permasalahan dan kekurangan yang ada pada data. Dengan menggunakan bantuan aplikasi know your data, dilakukan eksplorasi terhadap data yang akan digunakan. Pertama-tama, dilakukan inspeksi terhadap jumlah data yang tersedia, untuk masing-masing kelas data. Data dari masing-masing kelas ditunjukkan pada Table 1 .

Tabel 1. Jumlah Data Tiap Label

\begin{tabular}{cc}
\hline Label & Jumlah \\
\hline Parasitized & 13.779 \\
Uninfected & 13.779 \\
\hline
\end{tabular}

Kemudian, dilakukan inspeksi lanjutan terhadap citra sel ini, untuk melihat rentang ukuran citra ada pada data citra sel yang terinfeksi ini. Hasil inspeksi ukuran citra ditunjukkan pada Tabel 2.

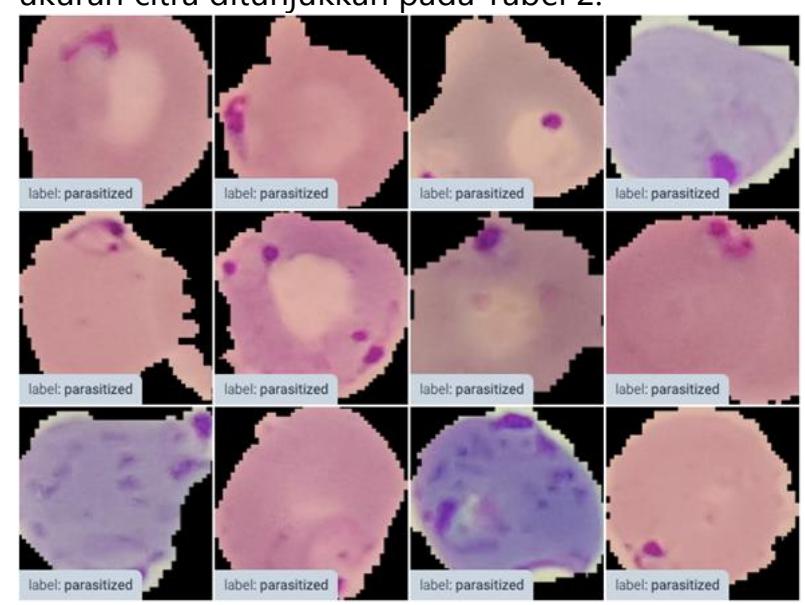

Gambar 4. Tampilan Sejumlah Data Citra Sel

Terinfeksi Parasit Malaria

Karena perbedaan ukuran tersebut, maka perlu dilakukan suatu transformasi terhadap data tersebut, untuk memastkan bahwa data citra masukan yang akan digunakan memiliki konsistensi pada ukuran. Kemudian, inspeksi selanjutnya dilakukan terhadap citra sel yang tidak terinfeksi parasit malaria. Hasil inspeksi ditunjukkan pada Gambar 5.

Tabel 2. Ukuran Citra Sel Terinfeksi

\begin{tabular}{lll}
\hline Ukuran & Minimum & Maksimum \\
\hline Tinggi & 40 & 385 \\
Lebar & 46 & 394
\end{tabular}

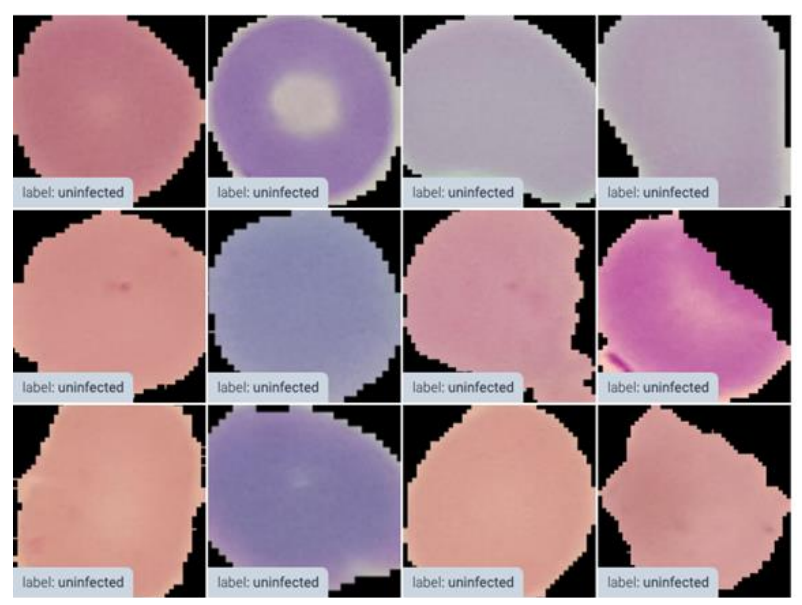

Gambar 5. Tampilan Sejumlah Data Citra Sel Tidak Terinfeksi Parasit Malaria

Pada hasil inspeksi tersebut, ditemukan bahwa data citra sel yang tidak terinfeksi parasit tidak memiliki ukuran yang seragam, diduga akibat pengolahan awal yang dilakukan oleh penyedia data, yang menghasilkan citra yang tersegmentasi. Selanjutnya dilakukan inspeksi lanjutan terhadap citra sel ini, untuk melihat rentang ukuran citra ada pada data citra sel yang tidak terinfeksi ini. Hasil inspeksi ukuran citra ditunjukkan pada Tabel 3. Dari seluruh hasil inspeksi tersebut, ditemukan perbedaan ukuran, sehingga tindakan selanjutnya yang perlu dilakukan adalah melakukan penyamaan ukuran terhadap seluruh data.

Tabel 3. Ukuran Citra Sel Tidak Terinfeksi

\begin{tabular}{ccc}
\hline Dimensi & Minimum & Maksimum \\
\hline Tinggi & 49 & 235 \\
Lebar & 49 & 247 \\
\hline
\end{tabular}

\section{Pelatihan dan Pengujian Model Dense Network}

Pada tahapan pertama pelatihan ini, akan dilakukan pelatihan terhadap model dense network. Pelatihan ini dilakukan dengan menggunakan parameter pelatihan sebagaimana telah ditetapkan pada subbab sebelumnya. Pelatihan menggunakan pendekatan coba-coba ini menyasar 20 epochs pelatihan, dengan menggunakan sebuah fungsi early stopping sebagai fungsi callback yang akan menyimpan konfigurasi terbaik, sekaligus menghentikan pelatihan apabila tidak didapatkan 
peningkatan kinerja setelah pelatihan sebanyak beberapa epoch yang telah ditentukan.

Pada pelatihan ini, pelatihan berhasil dilakukan sebanyak 11 epochs, yang mana pengaturan ini berada dibawah pengaturan awal pelatihan sebanyak 20 epochs. Ditarik kesimpulan bahwa telah terjadi early stopping. Pelatihan tidak menghasilkan peningkatan kinerja. Nilai loss validasi cenderung stagnan walaupun terhadi perbaikan nilai loss pelatihan. Terdapat indikasi bahwa model tidak memiliki kapasitas yang cukup untuk menyelesaikan permasalahan ini. Kemajuan pelatihan pada sisi loss dan akurasi ditunjukkan pada Gambar 6 dan Gambar 7.

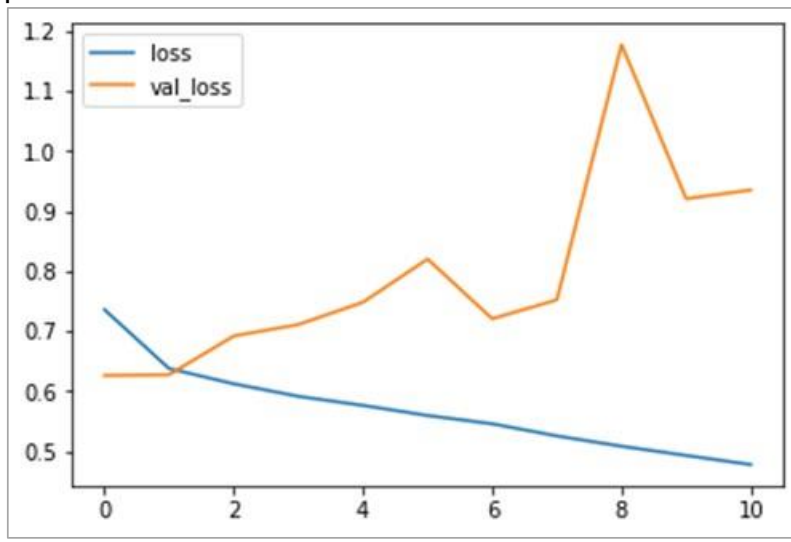

Gambar 6. Perkembangan Nilai Loss Berbanding Epochs Pelatihan

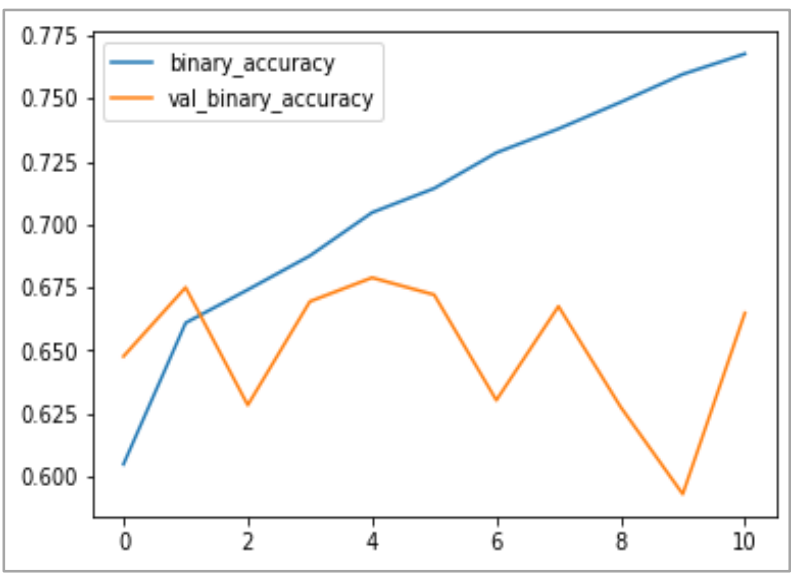

Gambar 7. Perkembangan Nilai Akurasi Berbanding Epochs Pelatihan

Kemudian, langkah terakhir pada tahapan ini, adalah melakukan pengujian menggunakan data tes. Data tes tidak digunakan sama sekali pada saat pelatihan dan validasi, sehingga diharapkan dapat lebih menunjukkan tingkat akurasi dari model ini. Tabel 4. Hasil Pengujian Model Dense Network

\section{$1 \quad \begin{gathered}\text { Dense } \\ \text { Network }\end{gathered} \quad 0.6213 \quad 64.78 \%$ \\ Pelatihan dan Pengujian Model Convolutional Neural Network}

Pada tahapan ini, model dilatih dengan menggunakan parameter yang sama dengan yang telah diterapkan pada pelatihan sebelumnya. Pelatihan ini dilakukan dengan menyasar sebanyak 20 epochs, yang dilakukan dengan menggunakan fungsi penyimpanan model terbaik, dan fungsi early stop untuk menghentikan pelatihan apabila sudah tidak terjadi peningkatan kinerja lebih lanjut. Dari pelatihan yang dilakukan, pelatihan dilakukan sebanyak 13 epochs. Dari pengaturan awal dimana disasar pelatihan sebanyak 20 epochs, maka dapat disimpulkan telah terjadi early stopping karena model tidak lagi mengalami peningkatan kinerja walaupun pelatihan terus berlanjut.

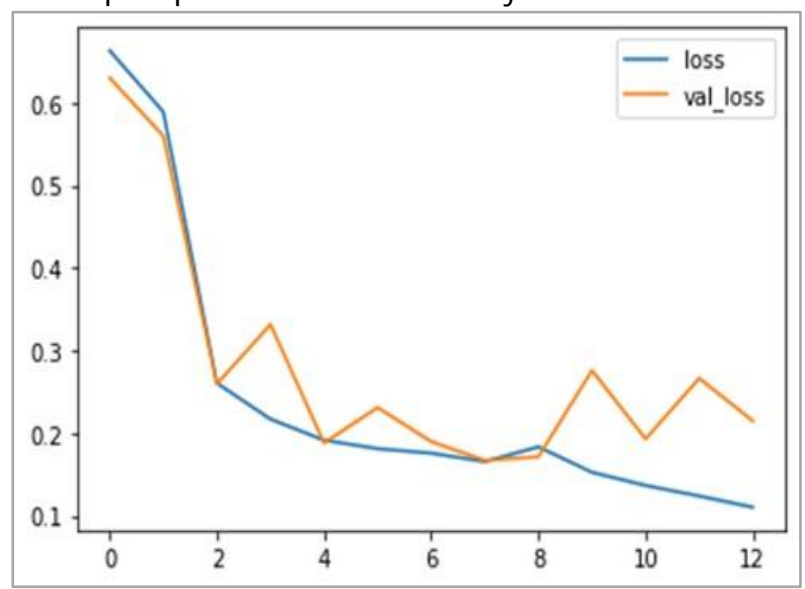

Gambar 8 Perkembangan Nilai Loss Terhadap Pelatihan

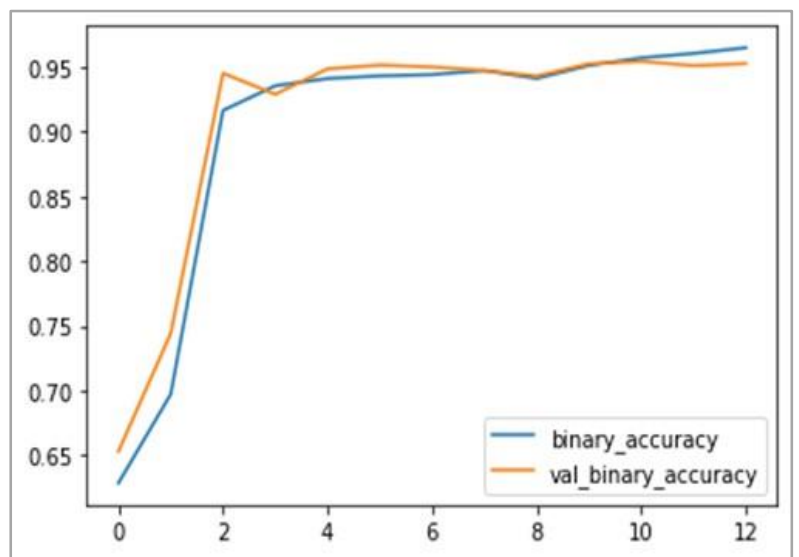

Gambar 9. Perkembangan Nilai Akurasi Terhadap Pelatihan

Dari hasil pelatihan, ditarik kesimpulan bahwa kinerja hasil pelatihan terjadi pada epoch ke 8, 
dengna nilai loss validasi sebesar 0.1669 , dengan akurasi validasi sebesar $94.7 \%$. Nilai ini sejalan dengan nilai loss pelatihan pada 0.1589 dengan nilai akurasi pelatihan sebesar $94.64 \%$. Walau nilai akurasi validasi ini masih lebih rendah dibandingkan akurasi pada tahapan berikutnya, nilai loss ini memiliki nilai kecil dan diharapkan memiliki konsistensi kinerja lebih tinggi dibandingkan konfigurasi setelahnya. Gambar 8 dan Gambar 9 menunjukkan perkembangan hasil pelatihan terhadap nilai akurasi dan loss pelatihan dan validasi.

Kemudian, langkah terakhir pada tahapan ini, adalah melakukan pengujian menggunakan data tes. Data tes tidak digunakan sama sekali pada saat pelatihan dan validasi, sehingga diharapkan dapat lebih menunjukkan tingkat akurasi dari model ini. Data tes ini merupakan data tes yang juga digunakan saat melakukan pengujian terhadap model dense network. Hasil uji terhadap model ditunjukkan pada Tabel 5.

Tabel 5. Hasil Pengujian Model Convolutional Neural Network

\begin{tabular}{cccc}
\hline No & Model & Loss & Akurasi \\
\hline \multirow{2}{*}{1} & $\begin{array}{c}\text { Convolutional } \\
\text { Neural Network }\end{array}$ & 0.5018 & $94.32 \%$ \\
\hline
\end{tabular}

\section{Evaluasi dan Perbandingan Kinerja}

Pada tahapan ini, akan dilakukan evaluasi, perbandingan, dan analisis terhadap kinerja dari masing-masing model yang telah dihasilkan. Pertama-tama, evaluasi kinerja akan dilakukan dengan melihat kemampuan prediksi masingmasing model terhadap permasalahan yang telah disajikan. Kinerja pada saat validasi dan pengujian untuk masing-masing model ditampilkan pada Tabel 6. Dari data tersebut, dapat dibandingkan bahwa model berbasis convolutional neural network memiliki nilai loss yang lebih rendah dan nilai akurasi yang lebih tinggi, baik pada saat validasi pelatihan, maupun pada saat pengujian.

Tabel 6 Hasil Pelatihan dan Pengujian Model

\begin{tabular}{llllll}
\hline No & \multicolumn{1}{c}{ Model } & Loss validasi & $\begin{array}{c}\text { Akurasi } \\
\text { validasi }\end{array}$ & $\begin{array}{c}\text { Loss } \\
\text { pengujian }\end{array}$ & $\begin{array}{c}\text { Akurasi } \\
\text { pengujian }\end{array}$ \\
\hline 1 & Dense network & 0.6263 & $64.77 \%$ & 0.6213 & $64.78 \%$ \\
2 & $\begin{array}{l}\text { Convolutional neural } \\
\text { network }\end{array}$ & 0.1669 & $94.70 \%$ & 0.5018 & $94.32 \%$ \\
& & & & \\
\hline
\end{tabular}

\section{KESIMPULAN}

Penelitian ini telah selesai dan beberapa temuan dihasilkan. Dua buah model neural network memiliki kinerja yang berbeda dalam melakukan prediksi terhadap citra sel yang terinfeksi malaria. Dari penelitian yang telah dilakukan, ditarik kesimpulan sebagai berikut:

1. Model convolutional neural network dan dense network untuk pengenalan citra sel malaria telah berhasil dikembangkan dengan bantuan software library tensorflow.

2. Model dense network memiliki akurasi deteksi sel terinfeksi malaria sebesar $67.89 \%$, sementara model berbasis convolutional neural network memiliki akurasi deteksi sel terinfeksi malaria sebesar $94.7 \%$.

3. Disimpulkan bahwa model berbasis convolutional neural network memiliki kinerja lebih baik pada penelitian ini, dibandingkan model berbasis dense network.

Saran dalam penelitian ini berupa kedua model masih berada dibawah tingkat akurasi yang dihasilkan oleh model CIFAR-10, yang mana hal ini mungkin disebabkan dari kurangnya kapasitas dari kedua model neural network. Pada penelitian selanjutnya dapat digunakan model dengan ukuran yang lebih besar (lebih lebar dan lebih dalam) untuk meningkatkan potensi peningkatan kinerja dari model. Hal lain yang dapat dilakukan adalah dengan melakukan kompresi terhadap ukuran citra sampel. Selain itu, dapat dicoba penggunaan transfer learning menggunakan basis model stateof-the-art dari percobaan-percobaan terdahulu.

\section{DAFTAR PUSTAKA}

Bias, S., Reni, S., \& Kale, I. (2018). Mobile Hardware Based Implementation of a Novel, Efficient, Fuzzy Bias, S., Reni, S., \& Kale, I. (2018). Mobile Hardware Based Implementation of a Novel, Efficient, Fuzzy Logic Inspired Edge Detection Technique for Analysis of Malaria Infected Microscopic Thin Blood Images. The 8th International Conference on Current and Future Trends of Information and Communication Technologies in Healthcare (ICTH 2018) (pp. 374381). Elsevier.

Bottou, L. (2018). Online Algorithms and Stochastic Approximations. Red Bank: AT\&T Labs-Research.

Centers for Disease Control and Prevention. (2020, February 19). Malaria Diagnosis - Microscopy. Retrieved from Centers for Disease Control and Prevention:

https://www.cdc.gov/malaria/diagnosis_treatme nt/diagnostic_tools.html 
He, K., Zhang, X., Ren, S., \& Sun, J. (2016). Deep Residual Learning for Image Recognition. Proceedings of the IEEE Conference on Computer Vision and Pattern Recognition (pp. 770-778). IEEE.

Jaeger, S. (2019, May 28). National Library of Medicine. Retrieved from LHNCBC: Ihncbc.nlm.nih.gov/LHC-

publications/pubs/Malaria-Datasets.html

LeCun, Y., Bottou, L., Bengio, Y., \& Haffner, P. (1998). Gradient-Based Learning Applied to Document Recognition. Proceedings of the IEEE (pp. 1-46). IEEE.

Pattanaik, P., Mittal, M., Khan, M., \& Panda, S. (2020, July 7). Malaria detection using deep residual networks with mobile microscopy. Journal of King Saud University, pp. 1-6.

Poostchi, M., Silamut, K., Maude, R., Jaeger, S., \& Thoma, G. (2018, April). Image analysis and machine learning for detecting malaria. Translational Research, pp. 36-55.

Primadi, O. (2017, April 3). Kenali Malaria Sebelum Lakukan Perjalanan ke Kawasan Timur Indonesia. Retrieved from Sehat Negeriku: https://sehatnegeriku.kemkes.go.id/baca/rilismedia/20170331/2720325/kenali-malarialakukan-perjalanan-kawasan-timur-indonesia/

Rajendran, S., Balasubramanian, D., \& Rajinikanth, V. (2020). Automated detection of plasmodium species using Machine-Learning technique. Diagnostics and Molecular Technology, pp. 192193.

Rosenblatt, F. (1958). The Perceptron: A Probabilistic Model for Information Storage and Organization in the Brain. Psychological Review, 386-408.

Sharma, A., Vans, E., Shigemizu, D., Boroevich, K., \& Tsunoda, T. (2019). DeepInsight: A methodology to transform a non-image data to an image for convolutional neural network architecture. Scientific Reports.

Shorten, C., \& Khoshgoftaar, T. (2019). A survey on Image Data Augmentation for Deep Learning. Journal of Big Data.

Zou, W., Wang, X., Sun, M., \& Lin, Y. (2013). Generic Object Detection with Dense Neural Patterns and Regionlets. NEC Laboroties America. 